\title{
El enemigo silencioso. Carta a una hija
}

\author{
The silent enemy. \\ Letter to a daughter
}

Anónimo

Citar como: Anónimo. El enemigo silencioso. Carta a una hija. Acta Med Grupo Angeles. 2021; 19 (2): 313. https://dx.doi.org/10.35366/100466

Dedicado a cada uno de los médicos que han enfrentado al COVID-19.

Hola. Estás muy pequeña aún y no tienes por qué saber todo lo que pasa en el mundo. Hace unos meses surgió una amenaza en China, algo que los seres humanos no entendemos... Eventualmente pasa esto en la naturaleza para lograr un equilibrio. En México empezamos a ver las noticias y a leer para entender de qué se trataba. Muchos tratamos de mantener la calma. No asustarnos. Otros desde el inicio entraron en pánico. Esta amenaza poco a poco se extendió por el mundo, se vieron afectados grandes países; no han podido contenerlo a pesar de tener a los mejores de su lado. España e Italia los más afectados. Muchos han caído, incluyendo a quienes luchan para detener esta amenaza.

El día 28 de febrero de 2020 nos enteramos de que había llegado a México... El primer afectado, algunos rieron, se tomó a la ligera, otros salieron a las calles a comprar productos para combatirlo, sin entender que la mejor batalla era mantener la calma y evitar las multitudes.

Leí la información sobre lo que nos acechaba. Y de pronto llegué a mi lugar de trabajo. No se parecía a lo que habíamos leído. Habíamos desarrollado una forma para hacerle frente, pero cuando nos dimos cuenta, nuestras defensas no eran tan fuertes como pensábamos... Nuestra líder empezó a trabajar más duro para hacerle frente. Poco a poco empezaron a llegar más personas afectadas. Cada vez que lo enfrentamos empezamos a entender, a tratarlo y combatirlo. Pero cada vez llegaban más personas. No sabes quién está afectado, es un enemigo silencioso e invisible. En este momento 25 de junio de 2021 se han reportado en todo el país 2'498,357 casos positivos confirmados, 232,346 defunciones acumuladas y 1'985,459 casos recuperados.* Pero siguen sin entender las personas que la forma de combatirlo es estar en sus casas y no salir.

Tengo miedo, este enemigo silencioso e invisible se Ilama COVID-19. Es un virus que ataca sobre todo a nivel pulmonar a las personas. Incluso los médicos no hemos aprendido de él, cómo se presenta, cómo ataca y cómo eliminarlo. Poco a poco aprendemos, pero en esta batalla habrá pérdidas, morirán personas, pacientes y médicos. Tengo miedo de llegar a la casa y contagiarte o contagiar a mamá. Tengo miedo de tocarte. Tengo miedo de dejarte, de que algo me pase, de enfermarme. Me toca por mi especialidad estar en la línea de choque, amo la medicina y amo mi especialidad, pero te amo más a ti. Los últimos días he visto más de estos pacientes. Y tengo miedo de no regresar. Sólo quiero decirte que te amo y que pase lo que pase siempre estaré a tu lado y te acompañaré hasta donde me lo permita la vida. Siempre te amaré. Eres la creación más bella del universo y tengo el privilegio de verte todos los días, eres mi corazón.

Tengo miedo. Pero tenemos que enfrentar al enemigo silencioso. Te ama papá...

Escrito para Sofía del Carmen de ocho meses de edad.

Al cabo de poco más de un año, hoy estoy enfermo, espero recuperarme y poder seguir escribiendo para ella y para la medicina.

Médico intensivista que solicita el anonimato.

\footnotetext{
* Cifras obtenidas de la página web del CONACYT: https://datos.covid-19.conacyt.mx/
}

www.medigraphic.com/actamedica

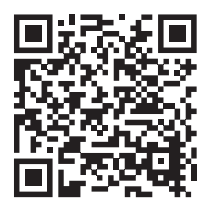

